\title{
Seroprevalence of Rickettsia rickettsii and Rickettsia parkeri in dogs during a Brazilian Spotted Fever outbreak in the State of Rio de Janeiro
}

\author{
[Soroprevalência de Rickettsia rickettsii e Rickettsia parkeri em cães durante um surto de \\ Febre Maculosa Brasileira no Estado do Rio de Janeiro] \\ I.T. Poubel ${ }^{1}$, N.C. Cunha ${ }^{1}$, A.B.M. Fonseca ${ }^{2}$, A. Pinter ${ }^{3}$, A.H. Fonseca ${ }^{4}$, \\ M.D. Cordeiro ${ }^{4}$, N.R.P. Almosny ${ }^{1}$ \\ ${ }^{1}$ Faculdade de Veterinária - Universidade Federal Fluminense - UFF - Niterói, RJ \\ ${ }^{2}$ Instituto de Matemática - UFF - Niterói, RJ \\ ${ }^{3}$ Superintendência de Controle de Endemias - São Paulo, SP \\ ${ }^{4}$ Instituto de Veterinária - Universidade Federal Rural do Rio de Janeiro - Seropédica, RJ
}

\begin{abstract}
The present paper is the first to perform this evaluation in dogs from the cities of Natividade, Porciuncula and Varre-Sai. The aim of this study is to search for Spotted Fever Group Rickettsia in canine sera using indirect immunofluorescence assay and to identify the probable causative agent of sera reactions in animals. Of the 253 sampled canines, $67.59 \%$ (171/253) were seroreactive for Rickettsia rickettsii and $11.07 \%$ (28/253) for Rickettsia parkeri, both in dilution 1:64. Titration of tested sera against $R$. rickettsii antigens reached 1:131.072 and, for R. parkeri, 1:4.096. We conclude that dogs are important sentinels for $R$. rickettsii infection, and can be infected regardless of sex, age, the habit of visiting woodlands or being in direct contact with equines and capybaras. Serological diagnosis has highlighted many dogs infected by $R$. rickettsii, and ambient conditions, such as the presence of flowing water bodies, was important for the occurrence of Brazilian Spotted Fever in the northwestern of Rio de Janeiro State.
\end{abstract}

Keywords: Spotted Fever Group Rickettsia, indirect immunofluorescence assay, ecological characterization, environmental characterization

\section{RESUMO}

O presente trabalho é o primeiro a ser realizado com cães nos municípios de Natividade, Porciúncula e Varre-Sai e tem por objetivo pesquisar Rickettsias do Grupo da Febre Maculosa em soros de cães, por meio da reação de imunofluorescência indireta, e identificar o provável agente causador da reação sorológica nos animais. Dos caninos amostrados, 67,59\% (171/253) foram sororreativos para Rickettsia rickettsii e 11,07\% (28/253) para Rickettsia parkeri, ambos em diluição de 1:64. A titulação dos soros testados contra antígenos de R. rickettsii chegou a 1:131.072, e para R. parkeri, 1:4.096. Conclui-se que cães são importantes sentinelas para a infecção por R. rickettsii, independente de sexo, idade, hábito de visitar ambientes florestais ou de estarem em contato direto com equinos e capivaras. $O$ diagnóstico sorológico permitiu evidenciar muitos cães infectados por R. rickettsii, e condições ambientais, como a presença de áreas ribeirinhas, foram importantes para a ocorrência de Febre Maculosa Brasileira na região noroeste do Estado do Rio de Janeiro.

Palavras-chave: Rickettsias do Grupo da Febre Maculosa, reação de imunofluorescência indireta, caracterização ecológica, caracterização ambiental

\section{INTRODUCTION}

Spotted Fever Group Rickettsia (SFGR) consists of a 60-species group, including Rickettsia rickettsii, the etiological agent of Brazilian

Recebido em 9 de agosto de 2016

Aceito em 9 de janeiro de 2017

E-mail: poubelit@gmail.com
Spotted Fever (BSF) (Parola et al., 2013). The transmission occurs via infected tick saliva, highlighting ticks of Amblyomma genus, which have been incriminated as vectors of this agent (Pinter e Labruna, 2006). Due to the proximity between humans and canines, zoonosis 
transmission can be easier (Szabó et al., 2001). Hence, dogs can act as surveillance means of rickettsioses in public health (Demma et al., 2006), considering their role as vector hosts of SFGR and sentinels to Rickettsia spp. transmitted infections (Nicholson et al., 2006).

Indirect immunofluorescence assay (IFA) is the gold standard test in the diagnosis of rickettsia infections (Gasser et al., 2001; Raoult and Parola, 2007) and recommendation is to perform serology with the known species in the study site (Horta et al., 2007).

Data on SFGR dispersion are located in the southern region of Rio de Janeiro State (RJ) (Gazeta et al., 2009; Cunha et al., 2014; Rozental et al., 2015; Cordeiro et al., 2015), while other regions do not have any studies, despite reports of BSF-related deaths. In 2014, there were reports of several confirmed cases and human deaths due to the BSF in the cities of Natividade, Porciuncula and Varre-Sai, as well as various suspected cases. So, in this study, two species of rickettsia genus were used, because they are recognized as pathogenic in Brazil. Rickettsia rickettsii, already known as etiologic agent of potential fatal disease (Brasil, 2016), and $R$. parkeri, recognized in a few cases of human infection, but already demonstrated as an emergent pathogen (Silva et al., 2011; Kaskas et al., 2014).

The purpose of the present study is to contribute for SFGR dispersion investigations during the human spotted fever outbreak in northwestern RJ. This is the first study performed in dogs in the cities of Natividade, Porciuncula and VarreSai. Therefore, the present study aims at observing the occurrence of anti-SFGR antibodies $R$. rickettsii and $R$. parkeri in canine sera and identifying the probable causative agent of the infection in animals.

\section{MATERIALS AND METHODS}

The research project was approved by the Ethical Committee on Animal Use under the number 270/2012. Descriptive observational studies were performed, followed by blood sample collections. This was initially performed preferably in probable locations of infection (PLI) for human cases and then on to adjacent areas. Samples were collected in July and August
2014 , in the cities of Natividade $\left(-21^{\circ} 02\right.$ ' 32 ' $\mathrm{S}$; 41 58 '24'O), Porciuncula (-20'57'46”'S; $\left.42^{\circ} 02^{\prime} 27^{\prime \prime} \mathrm{O}\right)$ and Varre-Sai (-20 $0^{\circ} 55^{\prime} 52^{\prime \prime} \mathrm{S}$; $41^{\circ} 52^{\prime} 07^{\prime}$ 'O), located in the northwestern RJ. The fieldwork began 20 days after the first human death by spotted fever in the region was confirmed.

Northwestern RJ is predominantly covered by seasonal semi-deciduous woodland containing Atlantic Forest vegetation, which is, however, formed by notably secondary vegetation where grasslands and pasture are the prevailing coverage. The Carangola river, an important subtributary of the Paraiba do Sul watershed, runs through Natividade and Porciuncula and its tributaries reach the city of Varre-Sai. The difference between urban and rural areas was established by the municipalities of the studied cities. Similar characteristics were noted in urban and rural areas including environmental conditions, namely the presence of rivers or tributaries, tall vegetation, stray dogs and domestic animals, such as equines, felines and bovines, and wildlife, such as capybaras.

Natividade and Porciuncula have a warm and humid tropical climate while Varre-Sai has a high-altitude tropical climate. The northwestern RJ has well-defined seasons with dry peaks in July and August. Average temperatures for the studied regions during collection months in 2014 were around $21^{\circ} \mathrm{C}$ with the lowest temperature at $17^{\circ} \mathrm{C}$ and maximum at $27^{\circ} \mathrm{C}$. Average rainfall was less or equal to $2 \mathrm{~mm}$ and relative air humidity around 75 to $80 \%$ (INPE, 2016).

The number of animals sampled was determined using the simple random sampling formula according to Pereira (2009), rendering a total of 253 samples with an estimated prevalence of $20 \%$ (Cunha et al., 2014). The animals were included in the study after those responsible for them had signed a free and clarified consent form. Once contained, without the use of anesthetics or tranquilizers, antisepsis was performed in venipuncture and blood sample collection sites, preferably in the jugular vein. The collected material was stored in EDTA-free tubes, properly identified and conditioned in icecooled coolers until sera extraction, which was performed on the same day of sample collection. Afterwards, sera were stored at $-20^{\circ} \mathrm{C}$ until serology was performed. 
Slides used for IFA were prepared with $R$. rickettsii (Taiaçu strain) and $R$. parkeri (At24 strain) infected vero cells (Pinter and Labruna, 2006; Silveira et al., 2007). Each vero cell batch was tested for fluorescence capacity at a 1:64 dilution and serology techniques were performed in accordance with previously established protocols (Horta et al., 2004). All orifices with more or less uniform and coccoid, bacillary or coccobacillary-shaped fluorescent spots were considered positive. In all slides positive and negative controls were used. The positive control was obtained from a dog of endemic area, naturally infected (Cunha et al., 2014). As the same, the negative control was from a dog previously tested. The samples were stored at $20^{\circ} \mathrm{C}$. Canine fluorescein isothiocyanate conjugated anti-IgG at a 1:80 dilution (SigmaAldrich Brasil Ltda ${ }^{\circledR}$, Brasil) was used. Reactive samples were diluted until negative results were obtained to attain final titration of each tested sera.

The frequency of $R$. rickettsii and $R$. parkeri seroreactive dogs was calculated in all of the studied cities and evaluated response variables at a 95\% significance according to the Chi-square test $(\chi 2)$ or Fisher's exact test (SPSS statistics package version 17).

\section{RESULTS AND DISCUSSION}

Samples from 253 dogs were obtained, of which $171(67.59 \%)$ had anti-R. rickettsii antibodies and $28(11.07 \%)$ were reactive to $R$. parkeri. The Table 1 shows the canine seroreactive distribution for each city.

Table 1. Frequency of reactive sera dogs in serology with 1:64 titer, using Rickettsia rickettsii and Rickettsia parkeri impregnated slides, from the cities of Natividade, Porciuncula and Varre-Sai (RJ), in July to August 2014

\begin{tabular}{lll}
\hline City & \multicolumn{2}{c}{ Reactive sera/tested sera $(\%)$} \\
\hline & \multicolumn{1}{c}{$R$. rickettsii } & \multicolumn{1}{c}{$R$. parkeri } \\
Natividade & $63 / 83(75.90)$ & $16 / 83(19.28)$ \\
Porciuncula & $75 / 112(66.96)$ & $12 / 112(10.71)$ \\
Varre-Sai & $33 / 58(56.90)$ & $0 / 58$ \\
\hline
\end{tabular}

The statistical analysis showed no association between the three studied cities regarding sera sample proportion of $R$. rickettsii reactive dogs ( $p$-value $=0.059)$; however, there was association between Natividade and Varre-Sai (p- value $=0.017$ ). The frequency of $R$. rickettsii reactive canine sera was markedly higher than described in other papers in BSF endemic areas in the Brazilian southeastern region (Sangioni et al., 2005; Horta et al., 2007), including five cities of RJ that are skirted by tributaries of the Paraiba do Sul river or directly by the Carangola river (Gazeta et al., 2009; Cunha et al., 2014). The difference between the frequency described in literature and those obtained in the present study can be explained by the epidemiological moment when the samples were obtained, when a human spotted fever outbreak occurred few days before the work filed. This reinforces the theory that ecological and environmental conditions can support $R$. rickettsii circulation (Angerami et al., 2009; Souza et al., 2015). These conditions were found in northwestern RJ such as the presence of flowing water bodies, equines, capybaras, ticks, scrubland, pasture, riparian vegetation and stray dogs.

Low frequencies of canine $R$. parkeri seroreactive results were obtained, supporting other studies in municipalities with BSF cases (Horta et al., 2007; Pena et al., 2009). In addition to the use of $R$. rickettsii strain, $R$. parkeri was chosen for IFA because is a SFGR and an emergent pathogen, and using at least two rickettsia species for IFA, the definitive diagnostic of infection can be done (Gasser et al., 2001; Raoult and Parola, 2007; Silva et al., 2011; Kaskas et al., 2014).

The considerable frequency of $R$. rickettsii seroreactive dogs in Natividade can be linked to specific epidemiological and ecological variables found in this city, considered PLI of $R$. rickettsii, where human infections culminated in death. This city has a distinct hydrography with the Carangola river running through the city's entire length and even bordering the city's commercial center. Studies have shown the importance of riverside communities regarding the possibility of human infection by $R$. rickettsii in endemic areas, where the majority of PLI are close to banks of flowing water bodies (Angerami et al., 2009; Souza et al., 2015; Nasser et al., 2015).

Besides the mentioned information, other factors can be related to the occurrence of $R$. rickettsii in the studied region. A research performed in a spotted fever endemic area in Sao Paulo State suggested capybaras (Hydrochoerus 
hydrochaeris) as a potential $R$. rickettsii maintaining species in nature (Perez et al., 2008). The presence of capybaras was widely reported by interviewed people, with occurrence in altered landscapes close to human habitats containing dogs and other domestic animals, in riverside communities with riparian vegetation and in human-inhabited urban areas. These characteristics were decisive for the occurrence of $R$. rickettsii in canine sera in other studies (Perez et al., 2008; Angerami et al., 2009; Souza et al., 2015; Nasser et al., 2015) and indicate the importance of ecology and the environment in the appearance of spotted fever in northwestern RJ.

BSF cases were linked to $R$. rickettsii seroreactive dogs using IFA and antibody titers found in canine sera decreased in periods following the human spotted fever outbreak (Galvão et al. 2014; Brasil, 2015). Although IFA does not discriminate between rickettsia species in cut-off, a four-fold increase in $R$. rickettsii antibody titers using comparative analyses with another rickettsia species such as $R$. parkeri or titers above 1:1.024 from a single canine sample must be found for a definitive diagnosis (Gasser et al., 2001; Raoult and Parola, 2007). So, to verify SFGR occurrence in canine sera and detect the probable causative agent of serology reactions, each obtained serum was tested to verify the presence of anti- $R$. rickettsii and anti$R$. parkeri IgG antibodies until final dilution. The results found are shown in Table 2 .

Table 2. Final titration and number of anti-Rickettsia rickettsii and anti-Rickettsia parkeri immunoglobulin $G$ antibody reactive canine sera in the cities of Natividade, Porciuncula and Varre-Sai (RJ) from July to August 2014

\begin{tabular}{lcccc}
$\begin{array}{l}\text { Final } \\
\text { Titration }\end{array}$ & $\begin{array}{c}\text { Rumber of reactive } \\
\text { canine sera }\end{array}$ & $\begin{array}{c}\text { Percentage (\%) of } \\
\text { reactive canine sera }\end{array}$ & $\begin{array}{c}\text { Rickettsia parkeri } \\
\text { Number of reactive } \\
\text { canine sera }\end{array}$ & $\begin{array}{c}\text { Percentage (\%) of } \\
\text { reactive canine sera }\end{array}$ \\
\hline $1: 64$ & 0 & -- & 5 & 17.86 \\
$1: 128$ & 2 & 1.17 & 0 & -- \\
$1: 256$ & 4 & 2.34 & 4 & 14.29 \\
$1: 512$ & 13 & 7.60 & 6 & 21.43 \\
$1: 1.024$ & 20 & 11.70 & 10 & 35.71 \\
$1: 2.048$ & 29 & 16.96 & 1 & 3.57 \\
$1: 4.096$ & 17 & 9.94 & 2 & 7.14 \\
$1: 8.192$ & 29 & 16.96 & 0 & -- \\
$1: 16.384$ & 26 & 15.20 & 0 & -- \\
$1: 32.768$ & 16 & 9.36 & 0 & -- \\
$1: 65.536$ & 13 & 7.60 & 0 & -- \\
$1: 131.072$ & 2 & 1.17 & 0 & -- \\
\hline
\end{tabular}

Dilutions of the $171 R$. rickettsii reactive canine sera varied from $1: 128$ to $1: 131.072$, while titrations of the $28 R$. parkeri reactive sera varied from 1:64 to 1:4.096. An experimental study showed that dogs susceptible to $R$. rickettsii can exhibit antibodies titers higher than 2.048, at least six months after infection (Piranda et al., 2008).

Cross-reactions may occur between rickettsia species, therefore, this study performed an analysis to evidence the frequency of dogs simultaneously reactive to $R$. rickettsii and $R$. parkeri. Several authors reported that to determine the etiologic agent, final titrations for the rickettsia agent causative of the events must be at least four-fold higher than other antigens tested (Gasser et al., 2001; Raoult and Parola, 2007; Horta et al., 2007). Final titrations of the present study are shown in Table 3.

Table 2 shows that $R$. rickettsii circulates in northwestern RJ, and that caused the infection of many canines. Out of the 21 dogs simultaneously reactive to $R$. rickettsii and $R$. parkeri, 15 lived in Natividade and six in Porciuncula. The statistical analysis showed association ( $p$-value $<0.001$ ) between results obtained from the sera of dogs simultaneously reactive to both rickettsia species, indicating the relevance of titers obtained for $R$. rickettsii at the expense of those obtained for $R$. parkeri. However, a possible IFA cross-reaction was indicated in five $(23.81 \%)$ of the analyzed 
canine sera samples. It was expected that some dogs would exhibit high titers for $R$. rickettsii, and also some seroreactiveness to $R$. parkeri. Knowing that cross-reactions may occur between rickettsia species (Gasser et al., 2001; Raoult and Parola, 2007), the titration of the samples was done. The titers obtained in this study are higher than others showed in studies previously done in areas with rickettsia circulation or in BSF outbreak areas (Horta et al., 2007; Pinter et al., 2008; Gazeta et al., 2009; Cunha et al., 2014; Rozental et al., 2015; Cordeiro et al., 2015).

Table 3. Sera titration of dogs simultaneously reactive to anti-Rickettsia rickettsii and antiRickettsia parkeri immunoglobulin G antibodies in the cities of Natividade and Porciuncula (RJ) from July to August 2014

\begin{tabular}{lll}
\multirow{2}{*}{$\begin{array}{c}\text { Number of } \\
\text { samples }\end{array}$} & \multicolumn{2}{c}{ Final titration } \\
\cline { 2 - 3 } & $\begin{array}{l}\text { Rickettsia } \\
\text { rickettsii }\end{array}$ & $\begin{array}{l}\text { Rickettsia } \\
\text { parkeri }\end{array}$ \\
\hline 1 & $1: 512$ & $1: 64$ \\
5 & $1: 65.536$ & $1: 1.024$ \\
6 & $1: 32.768$ & $1: 1.024$ \\
8 & $1: 16.384$ & $1: 256$ \\
9 & $1: 8.192$ & $1: 512$ \\
10 & $1: 8.192$ & $1: 512$ \\
11 & $1: 8.192$ & $1: 512$ \\
12 & $1: 8.192$ & $1: 512$ \\
15 & $1: 8.192$ & $1: 256$ \\
18 & $1: 2.048$ & $1: 1.024$ \\
24 & $1: 512$ & $1: 1.024$ \\
25 & $1: 1.024$ & $1: 256$ \\
40 & $1: 4.096$ & $1: 512$ \\
49 & $1: 512$ & $1: 1.024$ \\
55 & $1: 8.192$ & $1: 64$ \\
78 & $1: 65.536$ & $1: 64$ \\
188 & $1: 65.536$ & $1: 4.096$ \\
197 & $1: 8.192$ & $1: 1.024$ \\
201 & $1: 8.192$ & $1: 4.096$ \\
229 & $1: 1.024$ & $1: 1.024$ \\
279 & $1: 1.024$ & $1: 512$ \\
\hline
\end{tabular}

Of the dogs included in this study, 138/253 $(54.55 \%)$ were classified as crossbreeds. We noticed that the majority of these dogs were freerange animals and only one had no access to peridomiciliary environments. The dogs lived in houses with large backyards, farms or other rural estates which allowed contact with both external and indoor environments, including scrublands, pastures and areas with bodies of water such as rivers, streams, brooks and lakes.

Sex and age were not relevant in $R$. rickettsii seroreactivity of the studied dogs, although dogs less than one year old tended to be seroreactive. This data conflicts with literature, because in the present study, blood collection was performed in BSF outbreak, with a lot of infected dogs (Pinter et al. 2008; Cunha et al., 2014).

A statistical analysis was performed on $R$. rickettsii reactive and non-reactive dogs considering the habit of going into forest environments, contact with domestic animals and wildlife, as can be seen in Table 4 .

Most of the dogs did not have access to woodlands, and statistical analyses showed no association between dogs that were in constant contact with these areas and reactivity to $R$. rickettsii. Therefore, we notice that frequent contact of dogs with woodlands is not essential in the considerable detection of sera reactivity to $R$. rickettsii in canines. This result differs from a study performed in an endemic area of RJ, but the study shows the importance of dogs in contact with Amblyomma sp. ticks and with wild hosts and their parasites to peri-domestic environment (Cunha et al., 2014). So, regardless if whether the dogs had constant contact with riparian woodlands, other important factors can be attributed to the presence of $R$. rickettsii in these endemic areas such as the epidemiological situation of the studied location and constant contact of animals with infection-prone environments, e.g., flowing water bodies, scrublands and the presence of wild capybaras (Sangioni et al. 2005; Angerami et al., 2009; Souza et al., 2015; Nasser et al., 2015). Thus, this study presents the ecological and environmental characterization of the occurrence of $R$. rickettsii in spotted fever endemic areas in northwestern RJ. 
Table 4. Forest-visiting habit, contact with equines and capybaras related to positive reactions in 1:64 titrations in indirect immunofluorescence assay for Rickettsia rickettsii in the cities of Natividade, Porciuncula and Varre-Sai (RJ) from July to August 2014

\begin{tabular}{|c|c|c|c|}
\hline Variables & Number of tested animals & Number of reactive animals $(\%)$ & p-value \\
\hline \multicolumn{4}{|c|}{ Forest environment } \\
\hline Yes & 27 & $17(62,96)$ & 0.6643 \\
\hline No & 226 & $154(68,14)$ & \\
\hline \multicolumn{4}{|l|}{ Equines } \\
\hline Yes & 105 & $61(58.10)$ & 0.0094 \\
\hline No & 148 & $110(74.32)$ & \\
\hline \multicolumn{4}{|l|}{ Capybaras } \\
\hline Yes & 85 & $54(63.53)$ & 0.3936 \\
\hline No & 168 & $117(69.64)$ & \\
\hline
\end{tabular}

The fact that the studied dogs shared a habitat with capybaras during the spotted fever outbreak in northwestern RJ characterizes the importance of a shared environment between dogs and these wild animals, regardless of whether the dogs had constant contact with woodlands, since the capybaras circulated in both rural and urban environments along flowing water bodies. Also, the region's ixodid fauna is a crucial component for the occurrence of $R$. rickettsii in northwestern RJ (unpublished data). These data warrant constant epidemiological surveillance of spotted fever, given the occurrence of BSF-induced human deaths and the high frequency of $R$. rickettsii seroreactive canines that were in direct contact with humans, ticks and other domestic animals, such as equines, bovines and felines, and wild animals, such as capybaras.

According to Tab. 4, $74.32 \%$ of dogs that had no contact with horses were reactive to $R$. rickettsii, while $58.10 \%$ of dogs who had contact were reactive. It was expected that the contact with horses and their ticks could be a risk factor for the spread of $R$. rickettsii in endemic areas (Angerami et al., 2009; Gazeta et al., 2009), but the result of this study was contrary to literature. Statistical analysis revealed association between dogs with no direct contact with horses and reactivity in IFA, showing that the presence of horses was not essential for the circulation of $R$. rickettsii in the study area. Among the possible causes, the spread of infected ticks were made by capybaras, and the horses in the study area were well maintained, with greater access to medical and veterinary care than the sampled dogs. And there was no statistical association between dogs in contact with capybaras and reactivity in IFA. Data were collected by observation of the population for the presence of capybaras in the three municipalities studied, and may be underestimated, since these mammals are well suited to anthropogenic environments (Perez et al., 2008) and were widely observed by research team in riverside areas throughout the Carangola river.

The capybaras have a high reproductive capacity and few natural predators (Ferraz et al., 2007) and the presence and abundance of possible $R$. rickettsii vectors are related to areas with scrublands and riparian woodlands which can serve as hideouts for wild animals with which dogs can come in contact (Szabó et al., 2013; Souza et al., 2015) and can be found in northwestern RJ. The research was conducted during a spotted fever outbreak, when canines were infected by $R$. rickettsii, and where favorable environmental and ecological conditions for the maintenance of wild animals in contact with dogs and, consequently, for ticks which parasitize them (Szabó et al., 2013; Souza et al., 2015). Considering this, we can assert that canines were exposed to epidemiologically, ecologically and environmentally favorable conditions for $R$. rickettsii infection, regardless of frequent direct contact with equines and capybaras. We add to this the adaptiveness of capybaras to urban environments in the region based on reports of inhabitants of the studied cities, where capybaras could even be seen on city streets in late afternoons near the banks of water bodies.

Among the risk factors of $R$. rickettsii transmission in endemic areas, the presence of urban and periurban environments, characterized by their peripheral location to cities, near river banks or public parks, which contain tall vegetation and signs of degradation, can be 
mentioned (Souza et al., 2015). These characteristics were found in the northwestern RJ, in which many of the sampled animals lived near farms or other rural areas and accompanied workers in their daily tasks in town. In urban areas, a lot of dogs had constant contact with peridomiciliary environments and lived in backyards covered in dirt and tall vegetation (over 20 centimeters tall) and bordering water bodies which were inhabited by wild capybaras. Moreover, ectoparasiticide were irregularly applied on sampled animals. Thus, we can assert that regardless of the occurrence of seroreactive canines in urban or rural areas, the peculiar characteristics of the northwestern RJ yield important evidences regarding the circulation and dispersion of $R$. rickettsii in RJ.

\section{CONCLUSIONS}

Based on the data obtained in this study, we conclude that dogs are important sentinels for $R$. rickettsii infection, with serologic diagnosis of infection in a lot of dogs, with high final titrations for $R$. rickettsii. They can be infected regardless of sex, age, the habit of visiting woodlands or being in direct contact with equines and capybaras. Serological diagnosis has highlighted many dogs infected by $R$. rickettsii, and ambient conditions, such as the presence of flowing water bodies, was important for the occurrence of Brazilian Spotted Fever in northwestern of Rio de Janeiro State.

\section{ACKNOWLEDGMENTS}

We would like to thank those responsible for the studied dogs for their cooperation and for allowing us to collect the necessary biological material and the epidemiological control centers of the sampled cities for their partnership in developing this research project.

\section{REFERENCES}

ANGERAMI, R.N.; MORAIS, E.O.; KATZ, G.; SILVA, J.L. Brazilian spotted fever in the paediatric age-segment in the State of São Paulo, southeastern Brazil, 2003-2006. Clin. Microbiol. Infect., v.15, Suppl.2, p.205-206, 2009.
BRASIL. Ministério da Saúde. Sistema de Informação de Agravos de Notificação. Disponível em: http://dtr2004.saude.gov.br/ sinanweb/tabnet/dh?sinan/fmaculosa/bases/febre maculosabr.def $>$. Acessado em 07 set, 2015.

BRASIL. Ministério da Saúde. Sistema de Informação de Agravos de Notificação. Disponível em: <http://tabnet.datasus.gov.br>. Acessado em 24 mar, 2016.

CORDEIRO, M.D.; RAIA, V.A.; PINTER, A. et al. Seroprevalence of Rickettsia spp. and a study of the tick fauna in dogs from the municipality of Seropédica, State of Rio de Janeiro. Semin. Ciênc. Agrár., v.36, p.3787-3794, 2015.

CUNHA, N.C.; LEMOS, E.R.S.; ROZENTAL, T. et al. Rickettsiae of the Spotted Fever group in dogs, horses and ticks: an epidemiological study in an endemic region of the State of Rio de Janeiro, Brazil. Rev. Bras. Med. Vet., v.36, p.294-300, 2014.

DEMMA, L.J.; TRAEGER, M.S.; BLAU, D.M. et al. Serologic evidence for exposure to Rickettsia rickettsii in eastern Arizona and recent emergence of Rocky Mountain Spotted Fever in this region. Vector Borne Zoonot. Dis., v.6, p.423-429; 2006.

FERRAZ, K.M.P.; FERRAZ, S.F.B.; MOREIRA, J.R. et al. Capybara (Hydrochoerus hydrochaeris) distribution in agroecosystems: a cross-scale habitat analysis. J Biogeogr, v. 34, n. 2, p. 223-230, 2007.

GALVÃO, M.A.M.; SIQUEIRA， C.L.M.; FREITAS, R.N. et al. Brazilian spotted fever in Caratinga, Minas Gerais. Rev. Med. Minas Gerais, v.24, p.302-306, 2014.

GASSER, A.M.; BIRKENHEUER, A.J.; BREITSCHWERDT, E.B. Canine Rocky Mountain spotted fever: a retrospective study of 30 cases. J. Am. Anim. Hosp. Assoc., v.37, p.4148, 2001.

GAZETA, G.S.; SOUZA, E.R.; ABBOUDDUTRA, A.E. et al. Potential vectors and hosts of Rickettsia spp.: epidemiological studies in the Vale do Paraíba, state of Rio de Janeiro/Brasil. Clin. Microbiol. Infect., v.15, Suppl.2, p.269$270,2009$. 
HORTA, M.C.; LABRUNA, M.B.; PINTER, A. et al. Rickettsia infection in five areas of the State of São Paulo, Brazil. Mem. Inst. Oswaldo Cruz, v.102, p.793-801, 2007.

HORTA, M.C.; LABRUNA, M.B.; SANGIONI, L.A. et al. Prevalence of antibodies to spotted fever group rickettsiae in humans and domestic animals in a Brazilian spotted fever - endemic area in the state of São Paulo, Brazil: Serologic evidence for infection by Rickettsia rickettsii and another spotted fever group rickettsia. Am. J. Trop. Med. Hyg., v.71, p.93-97, 2004.

KASKAS, N.M.; LEDET, J.J.; WONG, A. et al. Rickettsia parkeri: eschar diagnosis. Am. Acad. Dermatol., v.71, 2014.

NASSER, J.T.; LANA, R.C.; SILVA, C.M.S. et al. Urbanização da febre maculosa brasileira em município da região Sudeste: epidemiologia e distribuição espacial. Rev. Bras. Epidemiol., v.18, p.299-312, 2015.

NICHOLSON, W.L.; GORDON, R.; DEMMA, L.J. Spotted fever group rickettsial infection in dogs from eastern Arizona: how long has it been there? Ann. N.Y. Acad. Sci., v.1078, p.519-522, 2006.

PAROLA, P.; PADDOCK, C.D.; SOCOLOVSCHI, C.L. et al. Update on tickborne rickettsioses around the world: a geographic approach. Clin. Microbiol. Rev., v.26, p.657-702, 2013.

PENA, D.C.; MAFRA, C.L.; CALIC, S.B. et al. Caracterização de Rickettsia spp. circulante em foco silencioso de febre maculosa brasileira no município de Caratinga, Minas Gerais, Brasil. Cad. Saúde Pública, v.22, p.243-244, 2009.

PEREIRA, M.G. Epidemiologia: teoria e prática. Rio de Janeiro: Guanabara Koogan, 2009. 596p.

PEREZ, C.A.; ALMEIDA, A.F.; ALMEIDA, A. et al. Carrapatos do gênero Amblyomma (Acari: Ixodidae) e suas relações com os hospedeiros em área endêmica para febre maculosa no Estado de São Paulo. Rev. Bras. Parasitol. Vet., v.17, p.210-217, 2008.

PINTER, A.; HORTA, M.C.; PACHECO, R.C. et al. Serosurvey of Rickettsia spp. in dogs and humans from an endemic area for Brazilian spotted fever in the State of São Paulo, Brazil. Cad. Saúde Pública, v.24, p.247-252, 2008.
PINTER, A.; LABRUNA, M.B. Isolation of Rickettsia rickettsii and Rickettsia bellii in cell culture from the tick Amblyomma aureolatum in Brazil. Ann. N.Y. Acad. Sci., v.1078, p.523-530, 2006.

PIRANDA, E.M.; FACCINI, J.L.; PINTER, A. et al. Experimental infection of dogs with a Brazilian strain of Rickettsia rickettsii: clinical and laboratory findings. Mem. Inst. Oswaldo Cruz, v.107, p.696-701, 2008.

RAOULT, D.; PAROLA, P. Rickettsial diseases. New York: CRC Press, 2007. [386p.].

ROZENTAL, T.; FERREIRA, M.S.; GOMES, R. et al. A cluster of Rickettsia rickettsii infection at an animal shelter in an urban area of Brazil. Epidemiol. Infect., v.143, p.2446-2450, 2015.

SANGIONI, L.A.; HORTA, M.C.; VIANNA, M.C.B. et al. Rickettsial infection in animals and Brazilian spotted fever endemicity. Emerg. Infect. Dis., v.11, p.265-270, 2005.

SILVA, N.; EREMEEVA, M.E.; ROZENTAL, $\mathrm{T}$. et al. Eschar-associated spotted fever Rickettsiosis, Bahia, Brazil. Emerg. Infect. Dis., v.17, p.275-278, 2011.

SILVEIRA, I.; PACHECO, R.C.; SZABÓ, M.J.P. et al. Rickettsia parkeri in Brazil. Emerg. Infect. Dis., v.13, p.1111-1113, 2007.

SOUZA, C.E.; PINTER, A.; DONALÍSIO, M.R. Risk factors associated with the transmission of Brazilian spotted fever in the Piracicaba river basin, State of São Paulo, Brazil. Rev. Soc. Bras. Med. Trop., v.48, p.11-17, 2015.

SZABÓ, M.P.J.; CUNHA, T.M.; PINTER, A.; VICENTINI, F.T. Ticks (Acari: Ixodidae) associated with domestic dogs in Franca region, São Paulo, Brazil. Exp. Appl. Acarol., v.25, p.909-916, 2001.

SZABÓ, M.P.J.; PINTER, A.; LABRUNA, M.B. Ecology, biology and distribution of spottedfever tick vectors in Brazil. Front. Cell. Infect. Microbiol., v.3, p.1-9, 2013. 